\title{
HIV-positive patients' and their families' comprehension of HIV- and AIDS-related information
}

\author{
Authors: \\ Gedina E. de Wet ${ }^{1}$ \\ Emmerentia du Plessis ${ }^{1}$ \\ Hester C. Klopper ${ }^{1}$

\section{Affiliations:} \\ ${ }^{1}$ School of Nursing Science, \\ North-West University, \\ Potchefstroom Campus, \\ South Africa
}

\section{Correspondence to:}

Emmerentia du Plessis

\section{Email:}

emmerentia.duplessis@nwu. ac.za

\section{Postal address:}

Private Bag X6001,

Potchefstroom, 2520,

South Africa

Dates:

Received: 18 Apr. 2011

Accepted: 05 Feb. 2013

Published: 11 Apr. 2013

How to cite this article: De Wet, G.E., Du Plessis, E. \& Klopper, H.C., 2013, 'HIVpositive patients' and their families' comprehension of HIV- and AIDS-related information', Health SA Gesondheid 18(1), Art. \#597, 11 pages. http://dx.doi. org/10.4102/hsag.v18i1.597

\section{Copyright:}

(C) 2013. The Authors. Licensee: AOSIS OpenJournals. This work is licensed under the Creative Commons Attribution License.
Despite acknowledgement of the importance of sharing HIV- and AIDS-related information with people living with HIV, it is still unclear as to what their actual comprehension is of this information. This research was part of a larger project, Tswaragano, conducted in the North-West Province, South Africa, which explored and described the competence, ability and strengths of the family of the HIV-positive patient during home support. This research focused on Potchefstroom in the North-West Province. This article focuses on research with the objective being to explore and describe the comprehension of HIV-positive patients and their families with regard to HIV-and AIDS-related information, and to formulate recommendations to improve their comprehension of this information. A quantitative, explorative and descriptive survey design was followed. Data were collected by means of questionnaires completed by HIV-positive patients $(n=79)$ and their family members $(n=34)$. Descriptive statistical analysis by means of frequency analysis was conducted. Ethical considerations and mechanisms to enhance validity and reliability are discussed. The results indicated that both HIV-positive respondents and their families face social and financial challenges due to unemployment and low income. A strength found in this research is that the majority of respondents are linked to a church, which can be a valuable platform to share information on HIV and AIDS. With regards to sharing, sources and comprehension of HIV- and AIDS-related information, it is apparent that respondents perceived that pre- and post-counselling provided an opportunity for information sharing, but that they need health care workers to spend more time with them, to be non-judgemental and to make more use of visual aids. It furthermore seems that the majority of HIV-positive respondents in this study did comprehend the need for and negotiate for safer sexual practices. It was concluded that although HIV-positive patients and their families have relatively good levels of comprehension of HIV- and AIDS-related information, there are certain gaps in their comprehension of this information. Accordingly, recommendations regarding improving comprehension of HIV-related information were formulated. Recommendations for nursing education, research and practice were formulated. These recommendations highlight the importance of openness in communication, building trust relationships, collaboration, cultural sensitivity and empowering HIV-positive patients and their families.

Ondanks erkenning aan die belangrikheid om MIV- en VIGS-verwante inligting met mense wat geraak word deur MIV te deel, is dit steeds onduidelik wat die betrokkenes se begrip van dié inligting is. Hierdie navorsing was deel van die Tswaragano projek wat MIV-positiewe pasiënte se familie se bevoegdheid, vermoëns en sterktes om pasiënte tydens tuissorg te ondersteun, te verken en beskryf en is uitgevoer in die Noordwes-Provinsie, Suid Afrika. Hierdie navorsing het op Potchefstroom in die Noordwes-Provinsie gefokus.Hierdie artikel fokus navorsing wat ten doel gehad het tot MIV-positiewe pasiënte en hulle families se begrip van MIV-en VIGS-verwante inligting te verken en te beskryf, en om aanbevelings om hulle begrip te verbeter, te formuleer. 'n Kwantitatiewe, beskrywende en verkennende opname-ontwerp is gevolg. Data is ingesamel deur vraelyste, voltooi deur MIV-positiewe pasiënte $(n=79)$ en familielede $(n=34)$. Beskrywende statistiese analise is deur middel van frekwensie-analise uitgevoer. Etiese aspekte en meganismes om geldigheid en betroubaarheid te bevorder word bespreek. Die resultate het getoon dat beide MIV-positiewe deelnemers en hul families se sosiale en finansiële uitdagings ervaar as gevolg van werkloosheid en lae inkomste. ' $n$ Sterkte bevind in hierdie navorsing is dat die meerderheid deelnemers gekoppel is aan ' $n$ kerk, wat ' $n$ waardevolle platform vir die deel van inligting oor MIV en VIGS kan wees. Met betrekking tot deel, bronne en begrip van MIV- en VIGS-verwante inligting is dit duidelik dat deelnemers van mening is dat pre- en post-berading ' $n$ geleentheid vir die deel van inligting is, maar dat hul 'n behoefte het dat die gesondheidswerker meer tyd saam met hul spandeer, nie-veroordelend is en meer gebruik maak van visuele hulpmiddels. Verder het dit geblyk dat die meerderheid MIV-positiewe deelnemers wel die nut van en onderhandeling vir veiliger seksuele praktyke begryp. Die gevolgtrekking was dat alhoewel MIV-positiewe pasiënte en hul families betreklike goeie begrip van MIV- en VIGS verwante inligting toon, daar sekere leemtes in hul begrip is. Daarvolgens is aanbevelings ter verbetering van begrip van MIV- en VIGS verwante inligting geformuleer. Aanbevelings is geformuleer vir verpleegonderwys, navorsing en praktyk. Hierdie aanbevelings beklemtoon die belangrikheid van openheid in kommunikasie, die bou van vertrouensverhoudings, samewerking, kultuursensitiwiteit en die bemagtiging van MIV-positiewe pasiënte en hul families. 


\section{Introduction}

Worldwide, HIV remains a major health challenge. This burden is especially prevalent in South Africa, where an estimated 5.7 million people are living with HIV (Joint United Nations Programme on HIV / AIDS [UNAIDS] 2008). This article describes research that was conducted in the North-West Province, one of the nine provinces in South Africa. The 2008 mid-year population of this province was 3.45 million people (Statistics South Africa [Stats SA] 2008:5), constituting $7 \%$ of the total South African population (Stats SA 2008:11). The World Health Organisation (WHO) and UNAIDS' epidemiological country profile on HIV and AIDS for South Africa (World Health Organisation \& UNAIDS 2009:1) indicated the prevalence of adults (aged 15-49) living with HIV in the North-West Province to be $15.8 \%-19.2 \%$ of the population in 2005. One of the major factors that contributes to the spread of this pandemic is ignorance and misinformation (Ojo \& De Lange 2011), also within families affected by HIV. Efficient HIV and AIDS information sharing is thus essential to allow the HIV-positive patient to comprehend HIV- and AIDS-related information, enabling them to provide sufficient information to their family members. As a consequence, family members will be able to support the HIV-positive patient more effectively if they sufficiently comprehend HIV- and AIDS-related information (Evian 2011).

Health professionals based at primary health care clinics in the North-West Province are key role players in the sharing of HIV- and AIDS-related information. However, various predisposing factors causing insufficient information sharing have been listed. Patients tend to interpret information incorrectly when HIV- and AIDS-related information has been shared in a non-therapeutic environment (Allender \& Spratley 2001:163). Hearing the news of a positive HIV status causes an internal crisis within the patient, impeding the patient's comprehension. HIV-positive patients have different ways of interpreting and internalising HIV- and AIDSrelated information whilst health professionals don't always establish the correctness and level of internationalisation of said information within the HIV-positive patient (Evian 2011). Another factor identified is the potentially impairing effect of Western communication techniques used for patients with a predominant Afrocentric perspective (Boikanyo 2001:24). Stigmatisation by professional and wellinformed persons can also impede information sharing (Petros 2011). Contextual factors experienced by the researcher that contribute to inadequate information sharing include limited time; lack of financial support; lack of available healthcare staff; facilities too small for sufficient health information in groups; lack of information material such as brochures in different languages; and high patient load in clinics.

\section{Statement of problem and research questions}

The abovementioned factors regarding information sharing could impede not only the HIV-positive patient's comprehension of HIV- and AIDS-related information but may also impact negatively (albeit indirectly) on his or her family's comprehension of the condition. This is not an encouraging position, as family members are the primary support for the HIV-positive patient (Evian 2011). If the HIVpositive patient and his or her family internalise HIV- and AIDS-related information, they will be in a better position to negotiate for or to provide support. A preliminary survey conducted in the Dr Kenneth Kaunda District by Roux and Wessels (1999) shows that families of HIV-positive patients do have a need for a better understanding of HIV- and AIDSrelated information in order to provide support. However, it was not clear what level of comprehension the HIV-positive patients and their families in the Dr Kenneth Kaunda District had regarding HIV- and AIDS-related. It was argued that insight into their level of comprehension could lead to the formulation of recommendations that would improve their understanding of HIV- and AIDS-related information.

Therefore, the following research questions were asked:

- What is the HIV-positive patient's comprehension of HIVand AIDS-related information?

- What is the HIV-positive patient's family's comprehension of HIV- and AIDS-related information?

- What can be done to improve the HIV-positive patient's family's comprehension of HIV- and AIDS-related information in order to empower them to support their family member?

\section{Objectives of the study}

The objectives of the study were thus:

- To explore and describe the HIV-positive patient's comprehension of HIV- and AIDS-related information.

- To explore and describe the HIV-positive patient's family's comprehension of HIV- and AIDS-related information.

- To formulate recommendations to improve the HIVpositive patient's family's comprehension of HIV- and AIDS-related information in order to empower them to support their family member.

\section{Theoretical framework Patient-health professional interaction}

This research was conducted within the framework of patient-health professional interaction, and placed within the context of HIV- and AIDS-related information sharing. A graphic depiction of the theoretical framework is found in Figure 1.

According to this framework the HIV-positive patient as an individual, his or her family and the health professionals (community) are in constant interaction. Decisions made by the HIV-positive patient influence the family and other individuals and vice versa (Minnie 2003:8), as all people are interdependent on each other. Thus, as implied in the introduction and statement of the problem, interaction in this case, sharing of information - between the health professional, the HIV-positive patient and the family 


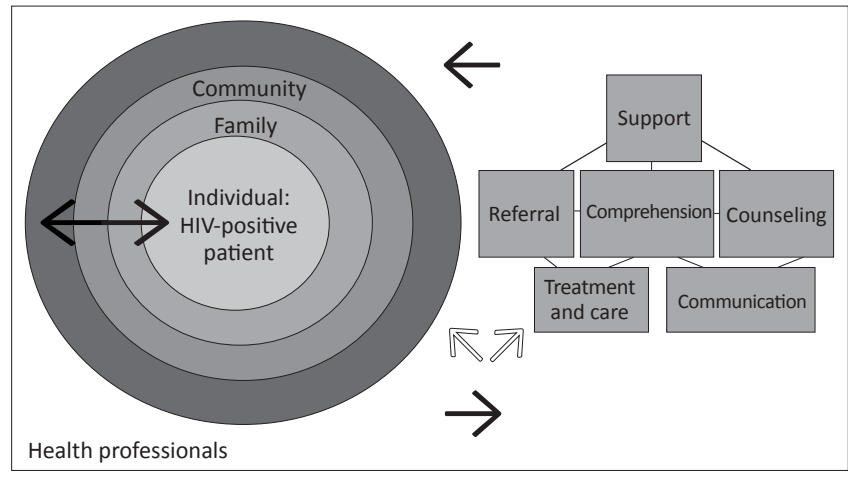

Source: De Wet (2007)

FIGURE 1: Patient-health professional interaction within the context of HIV-and AIDS-related information sharing.

influences comprehension of HIV- and AIDS-related information and, ultimately, the family's ability to support the HIV-positive patient.

The HIV-positive patient as an individual is a holistic being with physiological, psychological, socio-cultural, intellectual and spiritual dimensions and needs (Daniels 2005:864). This theoretical framework acknowledges that several factors influence the HIV patient's comprehension of HIV- and AIDS-related information, for example perception, literacy, emotional needs, support from his or her family, the nature of the shared HIV- and AIDS-related information, the approach in sharing the information, as well as his or her interaction with family and health professionals.

The family of the HIV-positive patient functions as his or her primary support system. Information on HIV and AIDS and their comprehension of this information have an influence on their competence with regard to supporting the HIV-positive patient. The functioning of the family, stigma, as well as myths and culture are factors influencing their comprehension of HIV- and AIDS-related information.

With regard to health professionals, one of their roles is to share HIV- and AIDS-related information, mainly with the HIV-positive patient, but also with his or her family. The interaction between the patient, family and health professional is very important when attempting to facilitate comprehension of said information. This interaction might also entail support, counselling, communication, treatment and care, as well as referral.

\section{Definitions}

\section{Health professionals}

The term 'health professionals' includes, for the purpose of this research, registered nurses working in primary health care (PHC) clinics qualified in community nursing, voluntary testing and counselling, as well as counselling skills. Also included are health care workers and health care advisors who are non-professional workers, working under the supervision of registered nurses, mainly responsible for screening, health education and counselling. It also includes voluntary workers who work under supervision of the registered nurse and who provide basic health care and counselling. Health professionals might also include members of the multi-professional team, such as medical doctors, social workers, pharmacists and dieticians, who may be involved in sharing HIV- and AIDS-related information. This research focused on registered nurses, health care advisors and volunteers.

\section{HIV- and AIDS-related information}

HIV- and AIDS-related information includes information on being HIV-positive, AIDS as a condition, stages of AIDS, transfer of the virus, treatment, and support needed by persons living with HIV.

\section{Information sharing, internalisation and comprehension}

Information sharing and internalisation refers to the process of communication between a sender of information (health professionals) and a receiver of information (the HIV-positive patient and his or her family), in this case information specifically regarding HIV and AIDS, in which the recipient is enabled to take in the information in such a way that this information becomes part of his or her frame of reference and is utilised in reaching a goal, in this case to support an HIVpositive family member. This implies comprehension, namely the ability to understand the meaning and importance of HIV- and AIDS-related information. Information sharing should thus take into consideration aspects such as the level of education, language, culture and needs of both the sender and recipient, whilst a process of clarifying what information has been internalised, and how, should be in place.

\section{Research design and method Design and context}

A quantitative, explorative and descriptive research design (Burns \& Grove 2005:24, 44) was followed in the form of a survey to explore and describe the HIV-positive patient and his family's comprehension of HIV- and AIDS-related information. In similar research, Kalichman, Cain, Knecht and Hill (2008) also followed a survey design to establish the HIV information needs of sexually-transmitted infection clinic patients in the USA.

The study described in this article was part of the Tswaragano Project and was conducted in the context of PHC clinics in two regions in the North-West Province. A pilot study to test the data collection instruments was conducted in a rural area, namely the Heuningvlei-area, as part of the Tswaragano Project, whilst the actual data collection took place in Potchefstroom. Potchefstroom is served by eight PHC clinics where up to 250 patients per week request voluntary counselling and HIV-testing.

\section{Research method}

Research method refers to population and sampling, data collection, ensuring rigour and data analysis (Klopper 
2008:69). These steps are discussed under the headings 'population and sampling', 'instruments', 'pilot study to test the instruments', 'research process', as well as 'data collection' and 'data analysis'. Ethical aspects as well as trustworthiness of results (validity and reliability) are also discussed.

\section{Population and sampling}

The population looked at was HIV-positive patients in Potchefstroom, North-West Province, as well as their families. The HIV-positive patients had already received pre- and post-HIV-testing and -counselling and had been informed about their HIV status. Because of the sensitive nature of the research, purposive sampling was conducted at the eight PHC clinics in Potchefstroom. Health professionals acted as intermediaries and assisted the researcher in approaching prospective respondents and in providing information about the research in order to ensure informed consent.

In order to assist these health professionals in identifying potential respondents, inclusion criteria were formulated for both the HIV-positive patients and the families of these patients. For the HIV-positive patients, the inclusion criteria stipulated that prospective respondents had to live in Potchefstroom; be aware of their HIV-status; be older than 18 years of age and should be able to give written informed consent for voluntary participation; should be able to understand English or Setswana; and should be available to participate in the research. The inclusion criteria for the family of the HIV-positive patient were: families should live in Potchefstroom; families should support the patient at home; 'families' can be members of the extended family, be neighbours of the patient, be part of the social or support systems of the patient or might be part of a church group.

A total of 105 questionnaires were distributed to HIVpositive patients, of which 79 were completed and submitted for analysis (a response rate of 75.23\%). This sample size was viewed as adequate by the Statistical Consultation Service of the North-West University, who indicated that 50-70 questionnaires were adequate for this research.

To identify family members, the HIV-positive patients were asked to invite their family members and to indicate whether they were available to participate. After the objectives of the research were explained to the family members, these members provided written informed consent. It was a challenge to get family members to participate voluntarily because of the sensitive nature of the research. Only 34 family members participated.

\section{Instruments}

Two questionnaires were developed in two phases for data collection. Constructs for measurement were identified and clarified with both subject experts in HIV and AIDS and a statistician. Thereafter a literature study was conducted for both the content of the questionnaire as well as general requirements in questionnaire development, such as appropriate length and correlation with the educational level of respondents. Both questionnaires were translated from Afrikaans into English and Setswana.

\section{Questionnaire 1: Explore and describe HIV-positive patient's comprehension of HIV- and AIDS-related information}

The questionnaire was divided into seven sections. These sections were:

- biographic data

- tuition, training and experience

- experiences of information sharing about HIV

- comprehension of HIV- and AIDS-related information

- comprehension of HIV-positive status and sexual practices

- comprehension of anti-retroviral medicine

- experience of the HIV-positive patient when he was informed about his status.

The total number of questions was 135, dominated by nominal scale dimensions that ranged between Yes/No/ Don't know/Not sure, with respondents being expected to indicate their answer with an X. Nine questions were openended.

\section{Questionnaire 2: Explore and describe HIV-positive patient's family members' comprehension of HIV- and AIDS-related information}

Questionnaire 2 included the following sections:

1. biographical information

2. tuition and training

3. knowledge of HIV

4. knowledge of anti-retroviral medication.

Ninety-three questions were asked of which five were open-ended, and 88 were closed questions with nominal scale dimensions ranging between Yes/No/Don't know/ Not sure, with respondents being expected to indicate their answer with an $X$.

\section{Pilot study of the instrument}

A pilot study was done in order to finalise the questionnaires. The questionnaires were completed by nine HIV-positive patients and their families. Based on the pilot study, the questionnaires were shortened, duplicate questions were eliminated and some questions were reformulated so as to clarify their meaning. A third choice category was added to some questions, namely 'I don't know/unsure'. A challenge that was identified during the pilot study was that translation of questions by the interpreters might have disguised the meaning of some of the questions. This issue could thus be addressed in training sessions with fieldworkers in the main study.

\section{Research procedure and data collection}

The professional nurses who acted as intermediaries were also trained as fieldworkers. They underwent training on the following aspects of the research procedure: objectives; identification of prospective respondents; assisting the 
researcher in obtaining written and informed consent from respondents; the anticipated research process; distribution, completion and collection of questionnaires; and assistance to illiterate respondents during the completion of the questionnaires. Questionnaires were available at the eight clinics and all respondents had the choice of either completing the questionnaires at the clinics, or having them conducted by the researcher at the respondents' houses. It took one month to collect the data.

\section{Data analysis}

Descriptive statistical analysis by means of frequency analysis, as described by Burns and Grove (2005), was conducted after all completed questionnaires were captured into the EpiData ${ }^{\mathrm{TM}}$ software (Lauritsen 2000-2008). The results regarding the HIV-positive respondents as well as their families are discussed in this article, following the discussions on ethical aspects and trustworthiness of the data.

\section{Ethical considerations}

Ethical permission from the North-West University (Certificate number:06K07), as well as the relevant authorities, namely the Department of Health and heads of PHC clinics, was obtained. Research experts also scrutinised the research proposal before commencement of the project. Further ethical considerations are discussed under potential benefits and hazards, as well as under protection of respondents.

\section{Potential benefits and hazards}

Benefits included the fact that respondents were given the opportunity to ask questions about the research. They were also allowed to ask questions on HIV- and AIDS-related topics after data collection was completed. Potential longterm benefits involve the implementation of the guidelines formulated based on the results of this study. Hazards included the issue of confidentiality, especially regarding HIV status. The researcher informed potential respondents that this information will be kept strictly confidential. Informed consent was obtained, and questionnaires were coded during data collection and analysis so as to ensure anonymity.

\section{Protection of respondents}

Because HIV is a sensitive topic, the population in this research project was regarded as being vulnerable. In an effort to protect potential respondents, intermediaries were asked to identify and invite potential respondents. This further contributed to confidentiality. Furthermore, all questionnaires were completed anonymously. Questionnaires were numbered for the purpose of data analysis.

\section{Validity and reliability}

In both questionnaires, strategies were implemented to enhance the validity and reliability thereof. Content validity was assured through a thorough literature study and by the critical evaluative input of subject specialists (Brockopp \& Hastings-Tolsma 1995:190). Face validity (Brink 2006:160) was enhanced by the literature study and evaluation by subject specialists, as well as by ensuring that the sample was representative of the population and acknowledging that the researcher's presence in the completion of the questionnaires could influence the respondents' behaviour. Strategies to enhance reliability included ensuring stability and equivalence (Klopper \& Knobloch 2010:322), mainly by conducting a pilot study in order to test the questionnaires.

\section{Results from the HIV-positive respondents \\ Section 1: Biographical information}

Frequency distribution was used to categorise the respondents' age, employment status, source of income, marital status and religious activities. Respondents' ages ranged between 19 years and 54 years with the highest frequency of $38 \%(n=30)$ in the age group 26 years -31 years, followed by $27 \%(n=21)$ of respondents between 32 years and 41 years and $20 \%(n=16)$ between the ages of 42 years and 54 years. In the age group 19 years - 25 years, 12 of the respondents (15\%) were HIV-positive. This age distribution is similar to the findings in research conducted by Wessels (2003:88-89), who mention that persons in these age groups are expected to be economically active, and that when they are affected by HIV and AIDS it leads to poverty and the risk of children acting as heads of families.

Most respondents $(74.7 \%)(n=59)$ were unemployed, of which $54.4 \%(n=43)$ were dependent on state subsidies because of their HIV-positive status. The remainder of the respondents were supported by family $(22.8 \%)(n=18)$ or by a life partner $(22.8 \%)(n=18)$. Of the $25.3 \%(n=20)$ employed respondents, $14.1 \%(n=11)$ received a monthly income of $\mathrm{R} 500$ - R1000 and 10.1\% $(n=8)$ received more than R1000 per month. One respondent did not indicate his or her income. Figure 2 illustrates the large proportion of respondents who were unemployed.

Only $16 \%(n=13)$ of the respondents were married, $44.3 \%$ $(n=35)$ were single and 20\% $(n=16)$ lived with a life partner. The remaining $19.7 \%(n=15)$ of respondents were either in a traditional marriage, divorced or widowed. The absence of support for single and unmarried HIV-positive people has been documented by Wessels (2003:90), who identified vulnerability to be financial, emotional and physical. Altogether, $83 \%(n=66)$ of the respondents stated that they were active in a church.

\section{Section 2: Tuition, training and experience}

Only $6.5 \%(n=5)$ of the respondents had no school tuition, whilst $93.5 \%(n=74)$ received some tuition. Of the $93.5 \%$, the majority $(32.9 \%)(n=26)$ completed Grade 7, 24\% $(n=19)$ completed Grade 10 and 30.3\% $(n=24)$ completed 


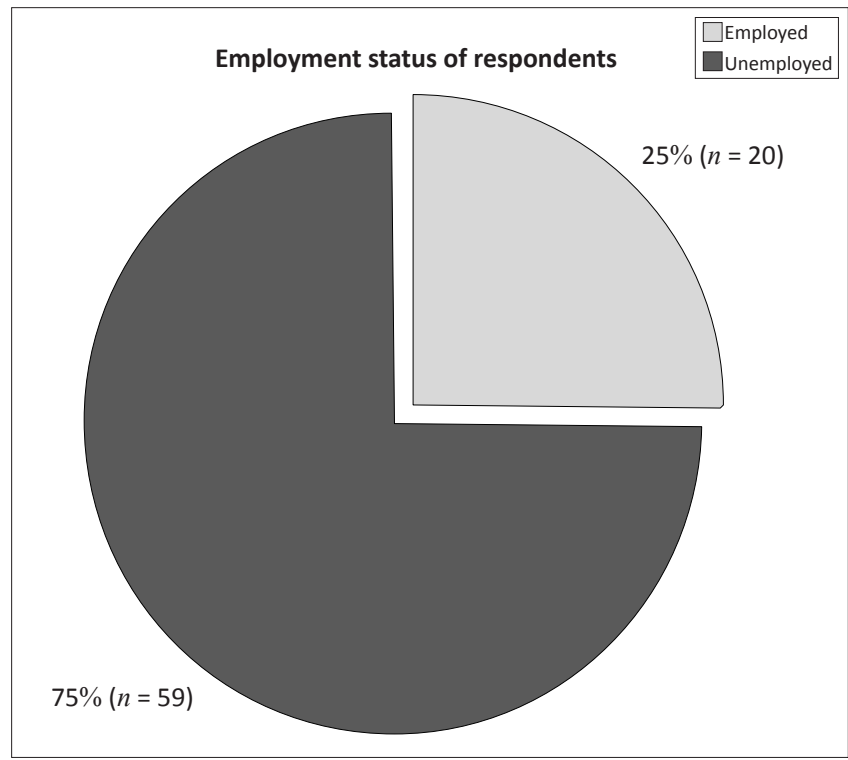

Source: De Wet (2007)

FIGURE 2: Employment status of respondents.

Grade 12 . Only $6.3 \%(n=5)$ had some form of tertiary training. The lack of training is associated with low income, as has been reported previously by Wessels (2003:90).

\section{Section 3: Experience of respondents regarding sharing of HIV- and AIDS-related information}

Respondents were informed by different health professionals of their HIV-positive status: $69.6 \%(n=55)$ of the respondents were informed by a health care worker at a PHC clinic, 25.3\% $(n=20)$ by a health care worker at a provincial hospital and $5.1 \%(n=4)$ by a medical practitioner in private practice.

\section{Pretest counselling}

Pretest counselling, in which blood was drawn after the respondents received counselling, was conducted with $93.7 \%$ $(n=74)$ of respondents. The respondents reported that the health care workers motivated the reason for an HIV blood test, explained the testing procedure and requesting that they repeat their understanding of the content of the counselling back to the health care worker. Only $6.3 \%(n=5)$ of the respondents did not receive pretest counselling.

\section{Post-test counselling}

Sufficient post-test counselling was reported by $92.4 \%$ $(n=73)$ of the respondents. However, $7.6 \%(n=6)$ of respondents reported that they did not receive post-test counselling and $5.1 \%(n=4)$ of respondents received posttest counselling but with insufficient time allowed by the health care worker for questions from the respondents after their HIV-positive status was revealed. The majority of respondents $(97.4 \%)(n=77)$ confirmed that their HIVpositive status was revealed to them in a confidential manner and in a private environment. Care workers were experienced as supportive and treated the respondents with respect during the revealing of their HIV-positive status (98.7\%) $(n=78)$. Most respondents $(94.9 \%)(n=75)$ experienced the information sharing by the health care worker as being clear and comprehensible, compared with $5.1 \%(n=4)$ who stated the opposite. Visual support was reported by only $3.8 \%$ $(n=3)$ respondents. A condemnatory attitude of health care workers was reported by $21.5 \%(n=17)$ of respondents, compared with $78.5 \%(n=62)$ of respondents who didn't report any experience of a condemnatory attitude.

\section{Section 4: Respondents' comprehension of HIV- and AIDS-related information}

\section{Sexual practices and the transfer of HIV}

Respondents were uncertain about how sexual practices influence the transfer of HIV. The majority of respondents $(88.6 \%)(n=70)$ reported that an HIV-positive patient can look healthy whilst being HIV-positive. The use of a condom to decrease the chances of the transfer of the virus was confirmed by $93.6 \%(n=74)$ of respondents, although $11.3 \%(n=9)$ were uncertain about whether the virus could be transferred more easily to a person that already had a sexually-transmitted disease. Some respondents (18.9\%) $(n=$ 15) were uncertain as to whether women could be infected more easily by the virus than men. The increased risk for HIV infection in homosexual relations was confirmed by $73.4 \%(n=$ 58 ) of respondents, whilst $14.0 \%(n=11)$ were uncertain. With regard to the risk of HIV infection through oral sex, $68.4 \%$ $(n=54)$ of the respondents confirmed that as an increased risk, compared with $16.5 \%(n=13)$ of respondents who were uncertain and $15.1 \%(n=12)$ who rejected the statement. The majority of respondents $(89.8 \%)(n=71)$ agreed that multiple sex partners increased the risk of HIV infection, but 6.3\% $(n=5)$ of the respondents felt that this was not true.

\section{Myths, ideas and sexual HIV transmission}

These results indicated that some of the respondents $(8.9 \%)$ $(n=7)$ agreed that an HIV infection could be cured when a person had sexual intercourse with a virgin or a young boy or girl, whilst $88.6 \%(n=70)$ of the respondents denied it. Being cured from HIV infection by having sexual intercourse with an elderly female was supported by $10.1 \%(n=8)$ of the respondents and denied by $87.3 \%(n=69)$.

\section{Social behaviour and HIV transmission}

The increased risk of HIV infection through coughing or sneezing was recognised by $17.7 \%(n=14)$ of the respondents, $74.7 \%(n=59)$ rejected this statement and $7.6 \%$ $(n=6)$ were uncertain. Transmission of HIV by means of kissing was repudiated by $70.8 \%(n=56)$ of respondents and supported by $16.4 \%(n=13)$. Although $82.2 \%(n=65)$ of the respondents denied that physical contact could increase HIV transmission, $6.3 \%(n=5)$ of the respondents were uncertain and $11.4 \%(n=9)$ agreed. Some respondents $(12.7 \%)(n=10)$ felt that HIV could be transferred by sharing a telephone and a plate, compared with $87 \%(n=60)$ of respondents who denied transmission through telephone sharing and $84 \%(n=$ 67 ) having this view regarding the use of the same plate. The risk of HIV transmission by means of blood was confirmed by $89.9 \%(n=71)$ of respondents, whilst $7.5 \%(n=6)$ were uncertain. Most respondents (79.7\%) $(n=63)$ acknowledged the increased risk of virus transmission through infected needles, but $13.9 \%(n=11)$ of respondents were uncertain. 
Tattooing as a high-risk practice for HIV transmission was supported by $39.2 \%(n=31)$ of respondents and rejected by $31.6 \%(n=25)$, whilst $29.1 \%(n=23)$ of the respondents were uncertain. Nearly half of the respondents $(45.5 \%)(n=36)$ agreed that infected sharp instruments and shaving blades could increase the risk of virus transmission, whereas $36.7 \%$ $(n=29)$ denied this statement and $17.7 \%(n=14)$ remained uncertain.

\section{HIV transmission and pregnancy, birth and breastfeeding}

Regarding the risk of virus transmission from an HIV-positive mother to the foetus or baby during pregnancy, birth and breastfeeding, $73.4 \%(n=58)$ respondents agreed that there is an increased risk for HIV transmission during pregnancy, $19 \%(n=15)$ repudiated this statement and 7.6\% $(n=6)$ of the respondents were uncertain. The increased risk for virus transmission during birth was confirmed by $84.8 \%(n=67)$ of the respondents and denied by $3.8 \%(n=3)$ respondents, whilst $11.4 \%(n=9)$ were uncertain. The majority $88.6 \%(n=$ 70 ) of the respondents agreed that there is an increased risk for HIV transmission during breastfeeding, but $7.6 \%(n=6)$ of respondents were uncertain and $3.8 \%(n=3)$ of respondents denied this statement.

\section{Information sources on HIV and AIDS}

The respondents indicated their sources of information on HIV and AIDS. This included more than one source of information, namely health care workers $(87.3 \%)(n=69)$, magazines $(67 \%)(n=53)$, schools $(31.6 \%)(n=25)$, television and radio $(87.3 \%)(n=69)$, clinics $(92.4 \%)(n=73)$ and family members $(50.6 \%)(n=40)$.

\section{Respondents' comprehension of symptoms associated with the early stages of HIV and AIDS}

The respondents' comprehension of the symptoms associated with the early stages of HIV is graphically portrayed in Figure 3.

\section{Respondents' comprehension of symptoms associated with later stages of HIV and AIDS}

Coughing was identified by $65.8 \%(n=52)$ of the respondents as being a later stage symptom of HIV. Most respondents $(72.1 \%)(n=57)$ agreed that skin rash is a symptom in later stages, whilst $13.9 \%(n=11)$ were uncertain. Enlarged lymph nodes were confirmed as a symptom by $63.2 \%(n=50)$, denied by $11.3 \%(n=6)$ and $24 \%(n=19)$ were uncertain, whilst $0.5 \%$ $(n=4)$ did not respond. Kaposi's sarcoma was confirmed by $54.4 \%(n=43)$, denied by $7.5 \%(n=6)$ and $36.7 \%(n=29)$ were uncertain, and $0.1 \%(n=1)$ did not respond to this question. Sudden weight loss was identified as a symptom by $87.3 \%$ $(n=69)$ of the respondents. Mouth sores were identified by $72.1 \%(n=57)$ of respondents, denied by $13.9 \%(n=11), 12.6 \%$ $(n=10)$ of respondents were uncertain, and $0.1 \%(n=1)$ did not respond to this question.

\section{Section 5: Respondents' comprehension of their HIV status and their sexual practices}

Condom use during sexual intercourse and disclosure to the sex partner of the preference to use condoms was confirmed by $97.4 \%(n=77)$ of respondents. Although 96.2\% $(n=76)$ of respondents agreed that condom use was mutually approved by themselves and their sex partners, $3.8 \%$

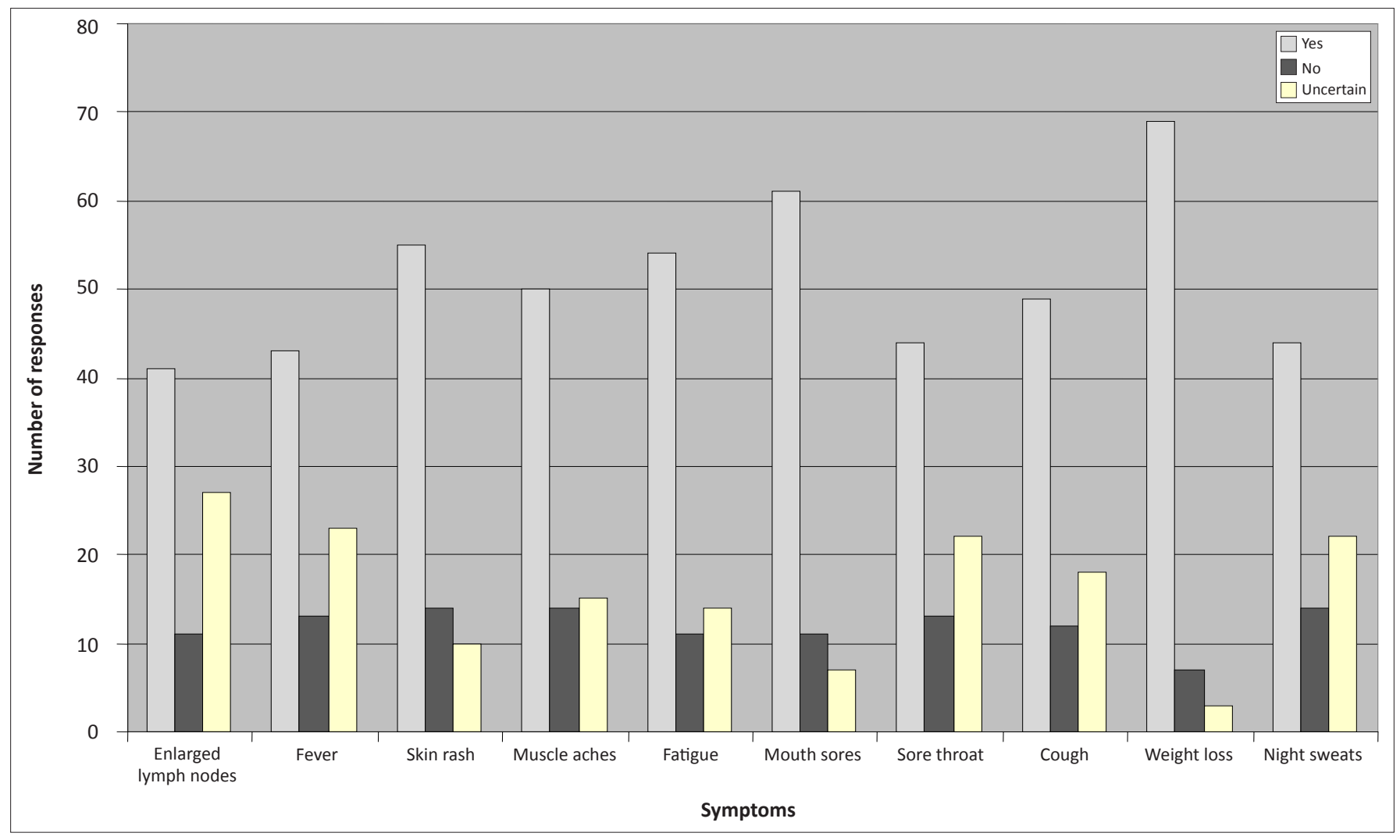

Source: De Wet (2007)

FIGURE 3: Respondents' comprehension of the symptoms associated with the early stages of HIV and AIDS. 
$(n=3)$ of respondents didn't agree. Altogether, 79.7\% $(n=63)$ of respondents had disclosed their HIV status to their families whilst $20.3 \%(n=16)$ had not.

\section{Section 6: Respondents' comprehension of antiretroviral medicine}

The availability of antiretroviral (ARV) medication at clinics was confirmed by $63.2 \%(n=50)$ of the respondents compared with $32.9 \%(n=26)$ that denied availability. Enhanced quality of life due to ARV therapy was confirmed by $96.2 \%(n=76)$ of the respondents, whilst $70.8 \%(n=56)$ of respondents took ARV medication exclusively and $26.5 \%(n=21)$ used alternative medicine and herbs.

\section{Section 7: Respondents' experience of their HIV status}

Discrimination was experienced by $46.8 \%(n=37)$ of respondents whilst $49.3 \%(n=39)$ did not experience this. Respondents preferred to share their HIV-positive status with parents, siblings, partners and friends. The majority of respondents $(75 \%)(n=57)$ did not want to discuss their status with their grandparents. However, the majority of respondents $(91.1 \%)(n=72)$ wanted support from family when they were ill, whereas $8.8 \%$ did not want family support during illness.

\section{Results from the HIV-positive respondents' families \\ Section 1: Biographical information}

Seeing as females are viewed traditionally as the family caregivers (UNAIDS 2001:37), it was interesting to find that family members of both genders are the primary family caregivers for HIV-positive patients, with $35 \%(n=12)$ being male and $65 \%(n=22)$ female. Family caregivers were predominantly between 34 and 41 years old and only 33\% $(n=11)$ were employed, whilst $67 \%(n=22)$ were unemployed, and $0.1 \%(n=1)$ did not respond to this question. Of the unemployed family caregivers, $67 \%$ $(n=22)$ received a government subsidy. The home language of family caregivers was Tswana $(41.1 \%)(n=17)$, Sotho $(23.5 \%)(n=8)$ or Zulu $(8.8 \%)(n=3)$. The remaining $1.7 \%$ $(n=6)$ were Afrikaans-, English- or Xhosa-speaking. More than half of the family caregivers $(52.9 \%)(n=18)$ were not married, 32.3\% $(n=11)$ were married and 1.4\% $(n=5)$ of family caregivers were either widowed or separated. A total of $85.2 \%(n=29)$ of the family caregivers attended various churches. The poverty-ridden reality of HIV was confirmed, not only amongst the HIV-positive patients but also amongst their family members.

\section{Section 2: Education and training}

School was attended by $82.4 \%(n=28)$ of family caregivers, whilst $17.6 \%(n=6)$ had no schooling. Of those who had received some schooling, $29.41 \%(n=10)$ had completed grade 12 , but none of the family caregivers had any tertiary education. Poor training and subsequent unemployment and poverty have also been identified as being a reality amongst the family members of HIV-positive patients.

\section{Section 3: Family's comprehension of the HIV- positive patient with regard to HIV and AIDS}

An overwhelming majority of family caregivers (79.4\%) $(n=27)$ agreed that an HIV-positive patient could look healthy whilst being infected. Prevention of HIV through use of condoms was confirmed by $94.1 \%(n=32)$ of family caregivers and $82.4 \%(n=28)$ agreed that being infected by a sexual transmitted disease could increase the risk of HIV infection. Family caregivers overwhelmingly agreed $(82.3 \%)(n=28)$ that females were at a greater risk of getting the virus but, $18.8 \%(n=3)$ were uncertain about this question. Homosexuality as a risk for contracting HIV was confirmed by $73.5 \%(n=25)$ of family caregivers and $70.5 \%(n=25)$ agreed that oral sex increased the risk of HIV infection. The majority of family caregivers $(82.3 \%)(n=28)$ agreed that multiple sex partners increased the risk for HIV infection. Cures for HIV by means of sexual intercourse with children or virgins was rejected by $88.2 \%(n=30)$ of family caregivers and $94.1 \%(n=32)$ rejected the possibility that sexual intercourse with an elderly woman could cure HIV. Transmission of HIV through sputum was denied by $85.2 \%$ $(n=29)$ of family caregivers, $83 \%(n=30)$ agreed that physical contact could not contribute to contracting the virus, $20.5 \%$ $(n=7)$ of family caregivers agreed that HIV could be transferred through kissing and 88.2\% $(n=30)$ denied that HIV could be transferred by sharing a telephone or a plate. HIV infection through HIV-infected blood transfusion was recognised by $91.17 \%(n=31)$ as being a possibility. Family caregivers $(64.7 \%)(n=22)$ were uncertain as to whether HIV could be transferred by sharing of contaminated needles and $20.5 \%(n=7)$ of family caregivers were uncertain as to whether HIV could be transferred by tattooing. HIV infection by sharing shaving blades and sharp objects was acknowledged as being true by $32.3 \%(n=11)$ of the respondents.

\section{Section 4: Family members' comprehension of antiretroviral medication}

Family members' level of agreement with specific statements on ARV medication was:

- ARV medication is available at clinics $(88.2 \%)(n=30)$.

- Quality of life is improved through ARV therapy (38.2\%) $(n=13)$.

- HIV-positive patients used ARV therapy exclusively $(82.3 \%)(n=28)$.

- ARV therapy could prevent HIV transmission (85.2\%) $(n=29)$.

- ARVs should be taken daily $(67.6 \%)(n=23)$.

- ARVs might make the HIV-positive patient feel sick $(26.4 \%)(n=9)$.

These results indicated the uncertainty prevalent amongst family members of HIV-positive patients regarding ARV therapy.

\section{Discussion}

This discussion refers to demographic factors; sharing, sources and comprehension of HIV- and AIDS-related information; as well as sexual practices, ARV medication and disclosure 
of HIV status. Throughout the discussion, the interaction between the HIV-positive patient as an individual, the family, the health care worker and the community, as referred to in the theoretical framework guiding this research, is apparent.

\section{Demographic factors}

From the results it is apparent that, in this study, both HIV-positive respondents and their families face social and financial challenges due to unemployment and low income. In addition, the majority of respondents did not have a life partner, increasing their socio-economic and emotional vulnerability. It is also evident that respondents have relatively low literacy levels, which might negatively impact on HIV-positive patients' as well as families' comprehension of HIV- and AIDS-related information. These social, economic, intellectual and emotional strains experienced by the HIV-positive patient, as well as the family, might be a limiting factor in information sharing and comprehension of HIV- and AIDS-related information, as they might focus more on surviving than on searching for information. This notion is confirmed by Ama and Seloilwe (2011), who found that families affected by HIV have emotional and socioeconomic needs, that they tend to be isolated due to difficult socio-economic circumstances, and that they lack adequate knowledge.

A strength found in this research is that the majority of respondents are linked to a church, which can be a valuable resource in mobilising support and in acting as a vehicle to facilitate collaboration between health care workers, HIVpositive patients and their families, as well as a vehicle for the sharing of information on HIV and AIDS. Petros (2011) recommends that involving religious organisations in support of HIV-positive patients and their families should be included in policies regarding HIV and AIDS care.

\section{Sharing, sources and comprehension of HIV- and AIDS-related information}

It seems that the HIV-positive respondents perceived that pre- and post-counselling is provided and that they provide an opportunity for information sharing. They did, however, indicate the need for more time to be spent with health care workers in order to ask questions, for health care workers not to take on a judgemental attitude and for more use to be made of visual aids. Furthermore, both the HIV-positive respondents and their families indicated that they receive HIV- and AIDS-related information from various sources in the community. Ojo and De Lange (2011) specifically emphasise the importance of appropriate and familiar visual aids in fostering comprehension with respect to HIV- and AIDS-related information.

Although both groups of respondents seemed to comprehend the HIV- and AIDS-related information, they still seemed to be uncertain regarding some sexual and social practices pertaining to the transfer of HIV, as well as some myths regarding the sexual transmission of HIV and the signs and symptoms of HIV and AIDS. Kalichman et al. (2008) found similar results amongst high risk HIV patients in the USA. Research conducted by Petros (2011) also confirms these findings, namely that families tend to be knowledgeable about HIV and AIDS, but that some still hold unorthodox and fatalistic beliefs about the disease.

\section{Sexual practices, antiretroviral medication and disclosure of HIV status}

It seems that the majority of HIV-positive respondents in this study did comprehend the need for and negotiate for safer sexual practices. Baiden and Rajulton (2011) found that although negotiation for safer sexual practices, such as condom use, are still not practised at the desired level (especially by African women), factors that improve condom use include sharing information with the sexual partner regarding how to avoid HIV, as well as regarding the benefits of condom use. This emphasises the importance of both sharing and comprehending HIV- and AIDS-related information.

Furthermore, whilst these HIV-positive respondents have a more positive view of ARV medication, it seems that their families are not certain about the value and effect of this medication. This might be complicated even more by the fact that HIV-positive respondents seemed reluctant to disclose their HIV-positive status to family members because of fear of stigmatisation, although they do have the need for family support. This interplay between ARV medication, disclosure and family support were investigated by Sanjobo, Frich and Fretheim (2009) in Zambia, and they found that disclosure and family support are facilitating factors in the HIV-patient's use of ARV medication. In addition, Makoae and Jubber (2008) found in Lesotho that non-disclosure of the HIV-positive family members' HIV-positive status hindered family support and family involvement in their care.

\section{Limitations of the study}

One of the limitations identified in this research was the limited diversity in respondents. That is to say, the respondents were mostly female and of various Christian denominations. These demographic variables might influence the research results. Language barriers were a third demographic variable as the researcher couldn't speak any of the indigenous black languages, although the mediators were fluent in these languages.

\section{Recommendations}

This article portrays HIV-positive respondents' and their families' comprehension of HIV- and AIDS related information. Recommendations drawn from the results have been formulated for nursing education, practice and research, and follow below.

Health professionals, namely the different categories of nurses and health care workers, as well as multi-professional team members, especially social workers, psychologists, educators and communication experts, should be made aware of their 
important role in the sharing of HIV- and AIDS-related information, and should engage in community projects with the purpose of collaborating with HIV-positive patients and their families, and creating awareness of. Such projects should not only focus on HIV- and AIDS-related information, but should also address basic health information, including life skills regarding coping with social, economic and emotional strains. It seems crucial that health professionals build a trust relationship with community members in order to ensure continuity and an openness in communication regarding HIV- and AIDS-related information. To this end, nursing students might play an important role, for example nursing students might be placed in the community to conduct home visits to families with an HIV-positive member in order to share HIV- and AIDS-related information. This confirms the importance of including issues on culture sensitivity as well as communication skills in the nurse education curriculum. Furthermore, collaboration with stakeholders in the community, such as non-governmental organisations and faith-based organisations seems critical, specifically in identifying resources for HIV-positive patients and their families and building a trust relationship with the community, as well as in creating a forum for sharing HIVand AIDS-related information. Further research on language and the cultural appropriateness of such information, in oral as well as written format, is needed.

More specifically, with regard to HIV- and AIDS-related information sharing by health professionals, the health professional needs self-knowledge, clinical knowledge, communication skills and self-confidence in order to establish a trust relationship between the HIV-positive patient and the health worker in which cultural diversity is tolerated. A trust relationship empowers the HIV-positive patient with regard to informed decision making. Sensitive themes in HIV counselling, such as dying and death, as well as sexual and social practices with regards to the transfer of HIV, need to be addressed. The South African cultural diversity increases the complexity of sharing HIV- and AIDS-related information. HIV- and AIDS-related information sharing is not only conducted by the health professionals but assimilated by the HIV-positive patient and family from various sources. Further research on this aspect, as well as on families' perceptions of ARV medication and disclosure of HIVpositive status amongst family members, is recommended.

\section{Conclusion}

This article addressed the problem that, despite acknowledgement of the importance of sharing HIV- and AIDS-related information with people living with HIV, it was unclear as to what their comprehension of said information was. As part of a bigger research project, focusing on the competence, ability and strengths of the family of the HIVpositive patient during home support, this research focused on the exploration and description of the HIV-positive patient's and his or her family's comprehension of HIVand AIDS-related information. A quantitative survey was conducted by means of questionnaires completed by HIVpositive patients $(n=79)$ and their family members $(n=34)$. The results indicate that although HIV-positive patients and their families have relatively good levels of comprehension of HIV- and AIDS-related information, some myths still remain, and there are certain gaps in their comprehension of this information. Recommendations for nursing education, research and practice are provided. These recommendations highlight the importance of openness in communication, building trust relationships, collaboration, cultural sensitivity and empowering HIV-positive patients and their families.

\section{Acknowledgements}

The authors would like to acknowledge NRF Thuthuka funding for the Tswaragano-project, of which this research formed part. This article is based on a Masters study conducted by G.E.d.W., supervised by E.d.P. and H.C.K.

\section{Competing interests}

The authors declare that they have no financial or personal relationship(s) which may have inappropriately influenced them in writing this paper.

\section{Author contributions}

All three authors contributed equally to the writing of the article. G.E.d.W. (School of Nursing Science, NWU) completed her Masters degree on this topic, whilst E.d.P. and H.C.K. (both School of Nursing Science, NWU) acted as supervisors and did the final preparation of the manuscript.

\section{References}

Allender, J.A. \& Spratley, B.W., 2001, Community health nursing: concepts and practice, 5th edn., Lippincott, Philadelphia.

Ama, N.O. \& Seloilwe, E.S., 2011, 'Analysis of the burdens of caregivers providing care to people living with HIV/AIDS in Botswana', South African Family Practitioner 53(1), 56-62.

Baiden, P. \& Rajulton, F., 2011, 'Factors influencing condom use among women in Ghana: an HIV/AIDS perspective', Journal of Social Aspects of HIV/ AIDS 8(2), 46-53. http://dx.doi.org/10.1080/17290376.2011.9724985 PMid:2323768

Boikanyo, P., 2001, 'Afrocentrism in the communication strategies used by the Department of Health and Social Developmental Welfare in the North West Province', Masters dissertation, School of Psychosocial and Behavioural Sciences, North-West University, Potchefstroom Campus (previously Potchefstroom University for Christian Higher Education).

Brink, H.I., 2006, Fundamentals of research methodology for health care professionals, Juta, Kenwyn, Revised by Van der Walt, C \& G.

Brockopp, D.Y. \& Hastings-Tolsma, M.T., 1995, Fundamental of nursing research, UNISA, Pretoria.

Burns, N. \& Grove, S.K., 2005, The practice of nursing research: conduct, critique and utilization, 5th edn., Elsevier Saunders, Philadelphia.

Daniels, R., 2005, Nursing fundamentals: Caring and clinical decision making, Thompson and Delmar Learning, New York.

De Wet, G.E., 2007, 'Riglyne vir die familie ter ondersteuning van die MIV-positiewe pasiënt', Meestersgraad verhandeling, Skool vir Verpleegkunde, NoordwesUniversiteit, Potchefstroomkampus.

Evian, C., 2011, Primary Aids Care, 5th edn., Jacana Education, Houghton.

Joint United Nations Programme on HIV/AIDS (UNAIDS), 2001, Fact sheet 7:7-2. Counseling and HIV/AIDS, UNAIDS, Geneva.

Joint United Nations Programme on HIV/AIDS (UNAIDS), 2008, 2008 Report on the global Aids epidemic, viewed 16 August 2009, from http://www.unaids.org/en/ dataanalysis/knowyourepidemic/epidemiologypublications/2008reportontheglo balaidsepidemic/ 
Kalichman, S.C., Cain, D., Knecht, J. \& Hill, J., 2008, 'HIV/AIDS information needs of sexually transmitted infection clinic patients: content analysis of questions asked during prevention counseling', Sex Education 8(1), 11-23. http://dx.doi. asked during prevention counseling,
org/10.1080/14681810701811787

Klopper, H.C., 2008, 'The qualitative research proposal', Curationis 31(4), 62-72. http:// dx.doi.org/10.4102/curationis.v31i4.1062 PMid:19653539

Klopper, H.C. \& Knobloch, S., 2010, 'Validity, reliability and trustworthiness', in K. Jooste (ed.), The principles and practice of nursing and health care, pp. 317-326, Van Schaik, Pretoria.

Lauritsen, J.M. (ed.), 2000-2008, 'EpiData Data Entry, Data Management and basic Statistical Analysis System', Odense Denmark, EpiData Association, 2000-2008, available from http://www.epidata.dk

Minnie, C.S., 2003, 'Die keuse van babavoedingswyse binne die MIV/VIGS-epidemie Voorligting implikasies', Meestersgraad verhandeling, Skool vir Verpleegkunde, Noordwes-Universiteit, Potchefstroomkampus (voorheen Potchefstroom Universiteit vir Christelike Hoër Onderwys).

Makoae, M.G., Jubber, K., 2008, 'Confidentiality or continuity? Family caregivers' experiences with care for HIV/AIDS patients in home-based care in Lesotho', Journal of Social Aspects of HIV/AIDS 5(1), 35-46.
Ojo, O.A. \& De Lange, W., 2011, 'Comprehension of HIV/AIDS messages in Lesotho: a case study of loveLife outdoor media campaign', Communicare 30(1), 21-46.

Petros, S.G., 2011, 'Supporting older caregivers to persons affected by HIV and AIDS. A policy framework', ESR Review 12(1), 25-28.

Roux, A. \& Wessels, C.C, 1999, Voorondersoek in die Potchefstroomdistrik: Kennis rakende MIV en VIGS verwysinginligting, ongepubliseerde verslag.

Sanjobo, N.,Frich,J.C.\&Fretheim,A.,2008, 'Barriersandfacilitatorstopatients' adherence to antiretroviral treatment in Zambia: a qualitative study', Journal of Social Aspects of HIV/AIDS 5(3), 136-143. http://dx doi.org/10.1080/17290376.2008.9724912 PMid:18979047

Statistics South Africa, 2008, Mid-year population estimates 2008, Statistics South Africa, Pretoria.

Wessels, C.C., 2003, 'Die opstel en evaluering van ' $n$ maatskaplikewerkbemagtigingsprogram vir gesinne van MIV positiewe/VIGS-pasiënte.' PhD proefskrif, Skool vir Psigososiale en Gedragwetenskappe, Noordwes-Universiteit, Potchefstroomkampus (voorheen Potchefstroom Universiteit vir Christelike Hoër Onderwys).

World Health Organisation \& Joint United Nations Programme on HIV/AIDS, 2009, South Africa: epidemiological country profile on HIV/AIDS, WHO, Geneva. 